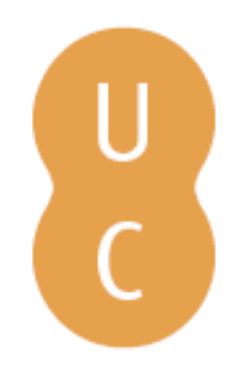

\title{
nombalina
}

\section{Variações de in-existência: narrativa poética e poema sinfónico em palavras}

Autor(es): Mariano, Maria do Rosário Neto

Publicado por: Imprensa da Universidade de Coimbra

URL

persistente:

URI:http://hdl.handle.net/10316.2/38709

DOI:

DOI:ttp://dx.doi.org/10.14195/978-989-26-1164-8_32

Accessed : $\quad$ 26-Apr-2023 13:39:57

A navegação consulta e descarregamento dos títulos inseridos nas Bibliotecas Digitais UC Digitalis, UC Pombalina e UC Impactum, pressupõem a aceitação plena e sem reservas dos Termos e Condições de Uso destas Bibliotecas Digitais, disponíveis em https://digitalis.uc.pt/pt-pt/termos.

Conforme exposto nos referidos Termos e Condições de Uso, o descarregamento de títulos de acesso restrito requer uma licença válida de autorização devendo o utilizador aceder ao(s) documento(s) a partir de um endereço de IP da instituição detentora da supramencionada licença.

Ao utilizador é apenas permitido o descarregamento para uso pessoal, pelo que o emprego do(s) título(s) descarregado(s) para outro fim, designadamente comercial, carece de autorização do respetivo autor ou editor da obra.

Na medida em que todas as obras da UC Digitalis se encontram protegidas pelo Código do Direito de Autor e Direitos Conexos e demais legislação aplicável, toda a cópia, parcial ou total, deste documento, nos casos em que é legalmente admitida, deverá conter ou fazer-se acompanhar por este aviso.

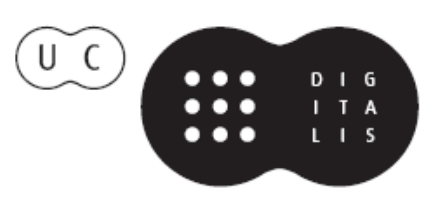


Maria do Rosário Neto Mariano

Centro de Literatura Portuguesa / Universidade de Coimbra

\section{VARIAÇÕES DE IN-EXISTÊNCIA: NARRATIVA POÉTICA E POEMA SINFÓNICO EM PALAVRAS}

No contexto da presente homenagem, escolhi abordar textos de duas autoras de Língua portuguesa que muito honram esse património comum com o pulsar singularíssimo da sua escrita, do pensar-sentir que nela toma corpo, beleza e não raras vezes magnificência.

Trata-se de Filipa Leal - uma voz (já) notável na geração de jovens poetas portugueses - e de Clarice Lispector, como se sabe, um nome consagrado não só na Literatura brasileira, como um pouco por todo o mundo.

De Filipa Leal elegi a obra mais recente - A Inexistência de Eva ${ }^{1}$, que designei por poema sinfónico em palavras, atendendo às suas características peculiares ${ }^{2}$.

De Clarice Lispector destaquei um conto - "Amor" - da obra Laços de Famíliả, colocando-a também em diálogo com o seu romance inaugural, Perto do Coração Selvagem ${ }^{4}$.

Não obstante a clareza das suas dissemelhanças, as autoras em apreço relacionam-se com a escrita ficcional e poética enquanto objeto estético e acontecimento em devir, lugar de perplexidades e revelações, de luz e obscuridade, mas sempre também, direta ou obliquamente, privilegiado horizonte de epifanias.

1 F. Leal, A Inexistência de Eva, Porto, Deriva, 2009.

2 Sobre o poema sinfónico e suas virtualidades artísticas, veja-se, por exemplo, Roland Candé, História Universal da Música, S. Paulo, Martins Fontes, 1994.

3 C. Lispector, Laços de Família, Lisboa, Relógio d' Água, s.d. (1ª ed., 1960, pela editora brasileira Francisco Alves).

4 C. Lispector, Perto do Coração Selvagem, Lisboa, Relógio d' Água, 2000. Considerado o melhor romance de 1943, a sua autora, então apenas com 23 anos, é agraciada com o Prémio Graça Aranha, da Academia Brasileira de Letras. Será traduzido para vários idiomas. 
De algum modo, estamos perante textos iniciáticos, expondo-nos personagens que, regressadas de uma só tarde ou de uma dimensão temporal mais ampla, não poderão reencontrar-se a partir das coordenadas que possuíam anteriormente. Uma nova existência terá de ser construída a partir dos fragmentos ou estilhaços da anterior, ainda que no essencial devam ser perspetivadas como in-existências - em fuga perante os aspetos mais vertiginosos de si mesmas na relação com a complexidade do mundo.

A escrita clariciana, no conjunto da sua extensa obra, apresenta as características de uma verdadeira escrita-mundo, revelando um universo próprio de atmosferas, personagens e sentimentos muito pouco consonantes com os cânones do romance realista, simbolista, ou de análise psicológica de esquema convencional, convocando, porém, vozes como as de V. Woolf, Faulkner, Joyce.

A sua fulgurante estranheza vai desvelando um estilo inimitável pela complexidade de sentido de que as palavras e sua tessitura sintática são investidas; pelo ritmo em crescendo, numa espiral de intensidade onde os paroxismos confinam, por vezes, com a vertigem e a náusea, acompanhando momentos de natureza epifânica.

Por seu lado, os protagonistas das suas narrativas caracterizam-se por um excesso de presença ou ausência de ser, sempre incoincidente com a necessária pertença à vida, em seus misteriosos ritmos e chamamentos ${ }^{5}$. Nesse sentido, a alacridade, a exaltação, o plenum são vivenciados como efémero ponto de equilíbrio nas personagens excessivas, prestes a converter-se em mal-estar, sofrimento, cansaço ou doença de ser - estados-limite de uma negatividade de que urge libertar a existência, para regressar às suas anteriores proporções: modestas, anódinas mas tranquilas.

\footnotetext{
5 Referindo-se às protagonistas femininas de dois dos seus romances mais singulares - Perto do Coração Selvagem e Uma aprendizagem ou O Livro dos Prazeres -, a ensaísta Lícia Manzo escreve sobre este tópico de "iniciação" ou "aprendizagem" do ser no mundo, começando desde logo pela vivência plena dos sentidos.

As respectivas protagonistas - Joana e Lóri -, e com diferentes níveis de sucesso, embora, tentam emergir desse alheamento denso que parece isolá-las da alteridade e da partilha contidas no mundo: "O "aprendizado" de Lóri constrói-se a partir das mais simples experiências, tais como: entrar no mar, observar a chuva caindo, olhar as frutas maduras na feira (...).

Cada experiência cotidiana, aos olhos de Lóri, é vivenciada como um pequeno milagre do qual ela extrai todo um universo de indizíveis e delicadas sensações. São elas que, pouco a pouco, se encarregam de restaurar formas de conexão suas com o mundo, há tanto tempo interrompidas.

O mesmo alheamento já se anunciava em Joana, há quase três décadas». Cf. Lícia Manzo, Era uma vez: EU, A não-ficção na obra de Clarice Lispector, Univ. Federal de Juiz de Fora, 2001, pp. 108-109.
} 
Um dos protagonistas de Perto do Coração Selvagem, Joana, manifesta essa insustentabilidade das vivências-limite no conhecimento do próprio amor:

Depois cessou a felicidade.

A plenitude tornou-se dolorosa e pesada e Joana era uma nuvem prestes a chover. Respirava mal como se dentro dela não houvesse lugar para o ar. (...)

Chorou tanto que não soube contar. Sentiu-se depois como se tivesse voltado às suas verdadeiras proporções, miúda, murcha, humilde. Serenamente vazia. Estava pronta.

Procurou-o então. E a nova glória e o novo sentimento foram mais intensos e de qualidade mais insuportável. ${ }^{6}$

Aliás, a escrita clariciana, tal como a de Filipa Leal, é amiúde uma metalinguagem, enquanto reflexão-indagação sobre o poder ou a impotência da palavra como revelador do mundo, sobretudo o interior - complexo, enigmático e dificilmente comunicável ou transponível na sua solidão.

A solidão ou o inalcançável, íntimo ser, o medo de experienciar a eternidade no seio da vida, as dúvidas perante a incompletude humana e os mistérios do mundo estão muito presentes nestas duas obras claricianas em apreço, sendo tópicos recorrentes em toda a sua obra 7 .

Frequentemente, a ausência de adequação ao mundo, nos protagonistas respetivos, resulta do excesso de pletora no mundo circundante - humano, animal, vegetal -, da sua inquietante exuberância, experimentando uma premente ameaça de dissolução perante tais manifestações de excesso vital.

Aliada a esse fenómeno recorrente, a estranha e fascinante causalidade que a autora estabelece relativamente aos comportamentos humanos, e os insólitos enunciados de valor comparativo, assumindo o comparado e o comparante uma familiaridade insuspeitável:

6 Cf. C. Lispector, op. cit., p. 97.

7 Destaco, nesse domínio, as obras: A Paixão segundo G.H., Rio de Janeiro, Rocco, 1988; Uma Aprendizagem ou O Livro dos Prazeres, Lisboa, Relógio d' Água, 1999; A Descoberta do Mundo, Lisboa, Indícios de Oiro, 2004. 
Ana respirava pesadamente. Mesmo as coisas que existiam antes do acontecimento estavam agora de sobreaviso, tinham um ar mais hostil, perecível ... O mundo se tornara de novo um mal-estar (...).

Perceber uma ausência de lei foi tão súbito que Ana se agarrou ao banco da frente, como se pudesse cair do bonde, como se as coisas pudessem ser revertidas com a mesma calma com que não o eram. ${ }^{8}$

Temerosas do incontrolável da vida, de suas faces hostis ou periclitantes, estas personagens procuram adormecer dentro da existência, resguardando-se no casulo conjugal e na sobreocupação, como quem foge de um perigo visível.?

O estado de espírito que procuram - temporário ou definitivo - é, assim, o de uma felicidade plácida, quase entristecida, sem horizontes maiores ou destinos que as venham convocar, desalojando-as da sua in-existência.

Porém, o temível irrompe como um assombro, desequilibrando a ordem frágil da superfície do mundo, a sua harmonia geométrica, precária, e instaurando uma geografia iniciática naquilo que antes fora percurso de familiaridades e rotinas, alheias ao fulgor da Alegria e do saber maior.

Com efeito, numa só tarde, Ana, a protagonista, desperta de um quotidiano dormente - onde todos os entes e objetos têm identidade e finalidade definitivas, lugar e atributos inquestionáveis e tranquilos - para as Revelações fascinantes e temíveis que nele deflagram.

E, como numa transmutação alquímica, o mundo pretensamente liso e transparente dos fenómenos torna-se perturbador e pleno de sombras e camadas, um mundo de segundo grau figurado na exuberância das formas verbais, adjetivação, sinestesias, animizações - inesperada luz sobre o real, própria dos acontecimentos epifânicos tão frequentes na ficção clariciana. ${ }^{10}$

$\mathrm{Na}$ anterior e precária ordem do mundo, flora e fauna eram idealizadas, e o que na natureza é selvagem e "cruel" aí se suspendia, ao olhar de Ana. Do mesmo

8 Cf. Id., "Amor", p. 20.

9 A própria autora, tantas vezes literariamente ressoando na sua obra, confessará: "Há tantos anos me perdi de vista que hesito procurar me encontrar (...). Eu tenho tanto medo de ser eu. Sou tão perigosa». (in Um Sopro de Vida, Rio de Janeiro, Ed. Nova Fronteira, 1988, p. 15).

10 Sobre o olhar fenomenológico de Lispector, a ênfase concedida ao estar-aí das coisas em toda a sua densidade matérica e anímica, veja-se: Regina Pontieri, "No Princípio era o Verbo-carne", in Clarice Lispector, Uma Poética do Olhar, Ateliê Ed., 1999. 
modo, os mais deserdados da vida encontravam-se sensatamente afastados do seu campo visual.

Por seu lado, o mundo tépido e quieto de Joana começa a ceder, a diluir-se, após um momento de revelação acontecido durante uma espécie de banho lustral:

Cerra as janelas do quarto - não ver, não ouvir, não sentir. Na cama silenciosa, flutuante na escuridão, aconchega-se como no ventre perdido e esquece. Tudo é vago, leve e mudo. (...) Por que surgem em mim essas sedes estranhas? A chuva e as estrelas, essa mistura fria e densa me acordou, abriu as portas do meu bosque verde e sombrio, desse bosque com cheiro de abismo onde corre água. E uniu-o à noite. ${ }^{11}$

Somente a partir dessas premissas se pode compreender a estranheza e a angústia e o fascínio que se apoderam de Ana, ao defrontar-se com a figura do cego "mastiga[ndo] goma na escuridão. Sem sofrimento, com os olhos abertos»" ou ao embrenhar-se no Jardim Botânico.

$\mathrm{Na}$ verdade, como uma enorme flor carnívora, o Jardim Botânico parecia querer tragá-la:

E de repente, com mal-estar, pareceu-lhe ter caído numa emboscada. Fazia-se no Jardim um trabalho secreto do qual ela começava a se aperceber (...).

A crueza do mundo era tranquila. O assassínio era profundo. E a morte não era o que pensávamos. ${ }^{13}$

Assim, nem a vida pujante, luxuriante até à náusea, nem a tumultuosa piedade-amor pelo cego se compatibilizam com a sua anterior vida, cercada de cuidados e sensatez e normatividade.

Esses acontecimentos epifânicos instituem a desordem e o desassossego no tranquilo labor do quotidiano existir, feito da neutralização de todos os focos de temor e de todos os excessos - do fascínio ao nojo, do Amor à angústia, pois Ana fora enfim

11 Cf. C. Lispector, Perto do Coração Selvagem, pp. 65-66.

12 Cf. Id., "Amor", p. 19.

13 Cf. Id., ib., p. 22. 
atingida pelo demónio da fé. (...) Com horror descobria que pertencia à parte forte do mundo - e que nome se deveria dar à sua misericórdia violenta? Seria obrigada a beijar o leproso, pois nunca seria apenas sua irmã. (...) Sentia-se banida porque nenhum pobre beberia água nas suas mãos ardentes. Ah, era mais fácil ser um santo que uma pessoa! Por Deus, pois não fora verdadeira a piedade que sondara no seu coração as águas profundas? Mas era uma piedade de leão. ${ }^{14}$

Ao contrário da mítica Eva, Ana é expulsa do anti-Paraíso dos seus dias e, quase misticamente, chamada a viver em simultâneo o Paraíso e o seu inferno: o Jardim Botânico, o amor violento pelo cego, o leproso, a multidão periclitante "à tona da escuridão». Pois, na sua extrema beleza, o Jardim causa-lhe "medo do Inferno" e, simetricamente, ao despertar para o fundo incógnito da alma, "atravessara o amor e o seu inferno».

Por outras palavras, nestes textos e no universo clariciano em geral, as personagens que conhecem estados extremos de beleza, amor, desejo e compaixão, são confrontadas com a sua própria inaptidão para os integrarem no quotidiano, por medo, evidentemente, e por estarem demasiado imersas no tépido torpor da comum in-existência. ${ }^{15}$

Paralelamente, em Perto do Coração Selvagem, os protagonistas experienciam a mesma incapacidade para integrar nos seus dias a magnificência dos sentimentos, e cada um irá em busca da sua própria via de evasão.

Eis por que entender a vida na sua magnitude e fundura, transformando esse entendimento em atitudes e ações concretas e harmoniosas, parece ser inacessível fora de um quadro periclitante, perigosamente próximo de alguma forma de perdição.

Impossuível como o vento, a luz, o tempo, Joana é metáfora da própria vida, como as rosas brancas são, entre as mãos de Otávio, metáfora de Joana:

E Otávio olhava-a esquecido de si próprio. A angústia terminava apertando seu coração, porque se ele quisesse tocá-la não poderia, havia um círculo intransponível

$14 \quad$ Id., ib., pp. 23-24.

15 Sobre uma poética-erótica do olhar e dos sentidos, na escrita clariciana, veja-se: Neiva Pitta Kadota, A Tessitura Dissimulada, O Social em Clarice Lispector, caps. 3, 4, S. Paulo, Edições Estação Liberdade, 1999. 
e impalpável ao redor daquela criatura, isolando-a. (...) No jardim da prima Isabel cresciam outrora rosas brancas. Ele olhava-as muitas vezes perplexo, sem saber de que modo tê-las, porque diante delas seu único poder, o de criatura, era vão. Encostava-as ao rosto, aos lábios, aspirava-as. Elas continuavam a tremer delicadamente viçosas. ${ }^{16}$

Desse modo, Otávio regressará ao torpor matérico e submisso daquela que, como Joana soubera perscrutar, "compreende a vida porque não é suficientemente inteligente para não compreendê-la ${ }^{17}$.

Quanto a Joana, resgatar-se-á da in-existência pela única via que consegue entrever como possível - prosseguindo, solitária, a misteriosa rota ("A viagem") que o seu "coração selvagem", feito da substância das estrelas, lhe for ditando, muito além de qualquer programática estrutura.

Enfim, como Otávio, mas mais estritamente refém dos "laços de família", Ana procurará refugiar-se da sua vertente abísmica, temível, no apaziguamento da rotina doméstica e, sobretudo, nos tépidos sentimentos familiares, na mão protetora e convenientemente, sensatamente humana, do marido, de modo a regressar à sua in-existência conciliadora e aquiescente, longe de cumes e abismos $^{18}$; longe da verdade, nessa confortável cegueira que lhe permitira envelhecer no interior da perigosa pujança da vida - não temendo, não tremendo, não Amando, não sendo mais que o ténue e frágil contorno de si mesma:

Eles rodeavam a mesa, a família. Cansados do dia, felizes em não discordar, tão dispostos a não ver defeitos. Riam-se de tudo, com o coração bom e humano. (...)

A cidade estava adormecida e quente. O que o cego desencadeara caberia nos seus dias? Quantos anos levaria até envelhecer de novo?19

16 Cf. Id., Perto do Coração Selvagem, pp. 182-183.

17 Cf. Id, ib., p. 78.

18 Revelando uma natureza excessiva, próxima da de Joana, a sua consciência, anteriormente apenas perceptivo-receptiva, isto é, flutuando em passividade, convertera-se, a partir das referidas epifanias, em consciência empática e reflexiva, logo, perigosa.

Implicitamente, Ana desejaria, como a passiva Lídia de Perto do Coração Selvagem, limitar-se a realizar no seu corpo e existência quotidiana as etapas da matéria orgânica em devir: respirar, comer, executar tarefas, reproduzir-se e morrer, enfim, sem ter verdadeiramente sido, sem ser autora e protagonista de um Destino; logo, uma mera in-existência em bruto de mulher-fêmea.

19 Cf. Id., ib., pp. 25-26. 
«Não fujas. Não esqueças» - disse a voz ${ }^{20}$, sibilina, insidiosa, alegoria da Tentação primordial, daquele que divide, separa, instaura a dissonância de alma.

De novo aqui a voz intenta reabrir o diferendo, a ferida, a divisão entre Eva e a humanidade, apartando-a pelo medo, estranho, difuso, omnipresente, rivalizando com o fascínio. ${ }^{21}$

Eva é uma personagem assombrada pelo medo e a inexistência, como avatares da ausência no interior do mundo, da vida. Desenraizada, perdida de si mesma, do passado, imersa na indeterminação e no espanto, Eva encontra-se numa espécie de mundo auroral, reinventado, fixando-se numa temporalidade sem tempos distintos, mensuráveis.

A matéria do seu mundo é uma substância poética e musical em um andamento, compacto e fluido simultaneamente, poema sinfónico composto de in-existências ou de ausências. Ausências de si no mundo e do mundo em si, numa quase inocência em vertigem face aos ritmos do dia, ao pulsar da noite: o anoitecer e o seu chamamento; o pássaro que repousa à sua porta e que esmagará, caso a abra aleatoriamente; a cidade que imagina líquida como um rio, e onde regressar não parece possível, onde regressar significa perder-se, uma vez mais.

Ao redor de Eva proliferam ameaças, negras premonições, avisos intimidatórios. Porém, esta não é a Eva temerária da narrativa bíblica, antes uma personagem enredada em estranhos medos, na inexistência e no seu fascínio, refém dos vaticínios da voz, do seu saber opressivo contrastando com o não-saber de Eva, a sua incerteza do mundo.

Esta estranha ausência-inexistência no interior do mundo, o semi-torpor dos sentidos - visão e audição, sobretudo - são múltiplas faces de uma alegoria da fuga mundi onde a inexistência artisticamente se ordena: tessitura de sons e sílabas, subliminar celebração do rasuramento dos seres e rostos na sua palavra testemunhal ou acusatória.

20 Trata-se de uma citação da obra aqui em apreço, referida na introdução a este texto: Filipa Leal, A Inexistência de Eva, p. 9.

21 Sobre o mito inaugural, genesíaco que Eva configura na narrativa bíblica e suas revisitações literárias e teológicas em geral, veja-se: Jean Chevalier, A. Gheerbrant, Dictionnaire des Symboles, Paris, Robert Laffont, 1982; Pierre Brunel (dir.), Dictionnaire des Mythes Littéraires, Paris, Éd. du Rocher, 1988. 
Nesse sentido, a voz - melífluo avatar da tentadora serpente - acaba constituindo-se alter-ego de Eva, o seu outro inumano, refratário ao remorso e à pertença, da humana condição declinando as situações de exposição à vulnerabilidade. ${ }^{22}$

Assim, se quiséssemos figurar cenicamente este poema sinfónico, teríamos, em primeiro plano, Eva, personagem despojada, talvez em certo sentido depurada mas não liberta, antes reclusa num espaço branco, inóspito, quase sem memórias - alegoria da ausência, do medo, da inumanidade, mas também de um fascínio que progressivamente se insinua, contraponto do temor.

Em segundo plano, no espaço cénico, alguns adereços e um cenário vazio e branco, de uma esterilidade lunar; apenas uma árvore aí viceja, frutifica: a macieira ancestral, as maçãs ainda vermelhas que Eva saboreia, ignorando o seu pesado simbolismo, da mesma forma que desconhece a herança do seu nome para a humanidade, segundo o Génesis.

Em fundo, a voz-off: de início apenas proferindo enunciados aparentemente inócuos; depois, sucessivamente, ela decanta-se na mente e na alma de Eva, paralisando-lhe a iniciativa, a acção, tentando subtraí-la ao fascínio pela vida que, a certa altura, nela aflorará. E assim a irá sitiando no interior do medo e da solidão extrema.

Na verdade, como profere a voz tentadora, Eva é a primeira mulher a habitar aquela sala branca, crua, cujas janelas de um branco opaco a impedem igualmente de se relacionar com o exterior, até mesmo com o pomar que a circunda de vida orgânica.

Réplicas de animais (em pedra, barro, madeira) ocupam uma arca - variação da Arca bíblica, porém repleta de seres inanimados.

Mais tarde, uma árvore cresce e frutifica no interior da sala e Eva (re)conhece então o fascínio pela vida e sua pujança, o perigoso fascínio, segundo a voz que a aprofunda na sua desagregação psíquica e existencial.

Com efeito, Eva manifesta uma estranha amnésia de quase todo o passado, tendo esquecido até mesmo os conceitos de vida e morte, de princípio e fim; as vivências do anoitecer, de uma qualquer cidade, da finalidade dos objetos.

22 Nesse sentido, a ótica interpretativa aqui proposta situa-se em clara posição de divergência face à linha hermenêutica seguida por Daniel Sibony, que identifica o feminino com um certo vazio identitário ou ausência de um si consistente, experienciada pela mulher em diversos contextos.

Veja-se, a este propósito, Daniel Sibony, Le Féminin et la Séduction, Paris, Grasset, 1986. 
O tempo, como os objetos, é enigmático e a sua medição inútil, inutilidade figurada no relógio de bolso, parado, que traz ao pescoço. Eva in-existe:

Ouviu: - Há um pássaro que todas as noites se deita à tua porta. Como não sabes a que horas anoitece, nem o que é anoitecer, se a abrires, esmagá-lo-ás.

(...)

Eva conhecia o medo inicial, não da solidão, não do pecado, mas de alguma inexistência. Trazia consigo a sensação da inexistência do mundo. Não sabia de onde chegara, e talvez por isso lhe parecesse errado partir.

Ouviu: - Se partires, não regressarás a lugar algum. Nunca se regressa partindo. ${ }^{23}$

A permanência na incompreensão e/ou desconhecimento do mundo é, em Eva, igualmente um antídoto contra a consciência da sua própria inexistência, essa luz insinuando-se oblíqua no esquecimento e na penumbra, ou no que na sucessão dos dias a preserva do medo, denso, excessivo:

Eva tinha uma ténue ideia do mar. Guardava-a como quem guarda a certeza de uma cidade líquida.

Ouviu: - Nisso que imaginas poder ser uma cidade, não sobreviverás. Há barcos e redes e homens que se afogam todos os dias.

(...)

No entanto, fascinava-a a incompreensão das coisas, como aos pensadores aterroriza a incompreensão do mundo. ${ }^{24}$

É, assim, uma estranha e fascinante personagem, perdida do passado e da tessitura do existir, mas também sensível à pujança vital da árvore, à frescura das suas flores escarlates, a esse perfume que desejaria partilhar com um qualquer pássaro que viesse recolher-se à sua porta, ao anoitecer. Sensível, ainda, à substância da felicidade, embora desconhecendo-a como matéria tematizável; dotada dessa sensualidade que como dom acompanha a própria inocência defrontando-se com o fluxo das coisas vivas.

23 Cf. Id., ib., p. 19.

24 Cf. Id., ib., pp. 22-23. 
Perante certos "quadros", recordamo-nos das cenas bíblicas de Giotto ou de Fra Angelico, embora saibamos que não é, nem poderia ser, a mesma inocência, apesar de uma certa genealogia comum:

Talvez Eva não soubesse falar, ainda ou já.

(...)

Ouviu: - Não precisarás de saber dizer as palavras. Para lá deste lugar, ninguém diz as palavras - que se pensam.

(...)

As pétalas caíam-lhe nos pés descalços.

Eram tão frescas e húmidas. Eva tocava-lhes com a atenção de quem descobre o mundo.

Devagar. Com elas enfeitou os cabelos, a arca, a sala, o ventre. (...) Se soubesse o que era a felicidade, Eva saberia ser feliz. ${ }^{25}$

Há nela reminiscências de algumas personagens femininas de Marguerite Duras, mas os seus contornos são ainda mais enigmáticos, a sua deriva da existência mais profunda e igualmente mais inalcançável a sua solidão - ontológica, psicossocial e mesmo biológica, constituindo a exuberância da árvore o seu único elo orgânico com os seres vivos.

Eva situa-se numa espécie de atopia e de acronia, porque não se trata apenas de um radical afastamento do seu espaço referencial de pertença, de afetos, de realização no mundo; em rigor, exilada, pelo esquecimento, da sua própria história de vida - da qual só recorda vagos indícios, nem mesmo fragmentos -, ela «Estava fechada na solidão mais absoluta, que é a de quem desconhece o contrário de se estar só» ${ }^{26}$.

Contudo, essa ausência de si em si, essa inexistência preservada pela sala-cidadela branca como uma grande névoa - também metáfora de depuração, espaço inaugural isento de referências do mundo exterior, onde algo de misterioso, de iniciático poderá vir a consumar-se sem interferências - não são definitivas.

25 Cf. Id., ib., pp. 25 e 32.

26 Os tópicos do medo, do inalcançável na alma, do abandono e de uma certa, irredutível solidão estão presentes igualmente noutras obras da autora, tais como: A Cidade Liquida e Outras Texturas, Porto, Deriva, 2006, e O Problema de Ser Norte, Porto, Deriva, 2008. 
Porque afetas à humana condição, igualmente são vulneráveis à efemeridade, ao abandono, à quebra de laços, por mínimos que sejam.

Também ela os conhecerá.

Ouviu: - O fascínio é o perigo em que te moves. Em breve, conhecerás o abandono.

(...)

Não dormira durante muitos dias, porque quisera estar atenta. Tão atenta. Agora não sabia descansar. Não sabia como ocupar o espaço. Não havia, em suma, um lugar que não fosse dessa árvore que se tornara branca como as paredes e as maçãs agora apodrecidas a um canto, gastas. ${ }^{27}$

Enfim, um dia, ao despertar, verifica o abandono dos frágeis e mínimos elos que a ligavam afetivamente ao mundo: a árvore, a arca, as maçãs, as janelas opacas.

Tudo desaparecera. Só o mar emerge, cercando-a. Aprisionada no próprio vazio, por ele sitiada, sem evasão visível, Eva confronta-se enfim com a inexistência na sua mais radical nudez - o desvanecimento dos últimos pontos de referência que possibilitavam o inexistir como manifestação do ser, mesmo se periclitante.

Tudo o mais é suspenso na indeterminação e na perplexidade. Para Eva. Para nós, que observamos com alguma perspetiva, nem tanto.

Nesse espaço intermédio, poder-se-á crer que uma epifania advirá, que abrirá o mar, confundindo e destronando o poder da voz, da inexistência como último acorde ainda audível.

27 Cf. Id. ib., pp. 34-35. 


\section{BIBLIOGRAFIA}

LEAL, Filipa, (2009). A Inexistência de Eva, Porto, Ed. Deriva. , (2008). O Problema de Ser Norte, Porto, Ed. Deriva. , (2006). A Cidade Líquida e Outras Texturas, Porto, Ed. Deriva.

LISPECTOR, Clarice, Laços de Família, Lisboa, Relógio d' Água, s.d. , (2000). Perto do Coração Selvagem, Lisboa, Relógio d’ Água. (1988). A Paixão Segundo G. H., Rio de Janeiro, Rocco. (1999). Uma Aprendizagem ou O Livro dos Prazeres, Lisboa, Relógio d' Água. (2004). A Descoberta do Mundo, Lisboa, Indícios de Oiro.

BRUNEL, Pierre (dir.), (1988). Dictionnaire des Mythes Littéraires, Paris, Ed. du Rocher. CANDÉ, Roland, (1994). História Universal da Música, S. Paulo, Martins Fontes.

CHEVAliER, Jean, GHEERBRANT, A., (1982). Dictionnaire des Symboles, Paris, Robert Laffont.

KADOTA, Neiva Pitta, (1999). A Tessitura Dissimulada, O Social em Clarice Lispector, S. Paulo, Estação Liberdade.

MANZO, Lícia, (2001). Era uma vez: EU. A não-ficção na obra de Clarice Lispector, Ed. da Universidade Federal de Juíz de Fora.

PONTIERI, Regina, (1999). Clarice Lispector, Uma Poética do Olhar, S. Paulo, Ateliê Ed.

SIBONY, Daniel, (1986). Le Féminin et la Séduction, Paris, Grasset. 